\title{
A dangerous precedent
}

\author{
A legal challenge to US stem-cell policy poses a serious threat to the federal funding system.
}

T he rift between opponents and supporters of research using human embryonic stem cells seems all but insurmountable, reaching to the core of individual notions of morality. That has meant that embryonic stem-cell research, in the United States and elsewhere, has in large part been delimited by governmental decree. Over the past decade, US scientists have pursued work on such stem cells - to a limited extent under former president George W. Bush and more freely under President Barack Obama - even while opponents have continued to challenge it.

One such recent challenge has overstepped the previous bounds of the battle, threatening not only embryonic stem-cell research, but also the very framework of federal funding for science. Both funders and the scientific community must speak out to ensure that the dangers it poses are clearly recognized.

Last August, several Christian groups joined forces with two scientists to file a lawsuit against the US Department of Health and Human Services and the National Institutes of Health (NIH). The lawsuit charged that the Obama administration's embryonic stem-cell policy violates the Dickey-Wicker Amendment, a law that prohibits federal funding of research on human embryos. The suit was dismissed on the grounds that the plaintiffs had no real standing in the case - that is, no tangible interest in its outcome.

But on 25 June, the Court of Appeals in Washington DC reversed the dismissal on the basis of an appeal made by the scientist plaintiffs: James Sherley, a researcher who works with stem cells derived from adult tissue at the Boston Biomedical Research Institute in Watertown, Massachusetts, and Theresa Deisher, research and development director of the firm AVM Biotechnology in Seattle, Washington. To justify their standing as plaintiffs, they argue that because federal funding is now going towards research on embryonic stem cells, there are fewer funding dollars - and therefore "increased competition" — for research using adult stem cells.

\section{Plagiarism pinioned}

\section{There are tools to detect non-originality in articles, but instilling ethical norms remains essential.}

$t \mathrm{t}$ is both encouraging and disheartening to hear that major science publishers intend to roll out the CrossCheck plagiarism-screening service across their journals (see page 167).

What is encouraging is that many publishers are not only tackling plagiarism in a systematic way, but have agreed to do so by sharing the full text of their articles in a common database. This last was not a given, considering the conservatism of some companies, yet it was a necessary step for the service to function - the iThenticate software used by CrossCheck works by comparing submitted articles against
It is hard to say which is more disturbing - the argument made by the two scientists or the fact that it was accepted by the court. Both issues set a dangerous precedent by suggesting that researchers are legally entitled to a certain portion of the funding pie, and that changes in a federal agency's research priorities - which often occur as scientific disciplines evolve - open the agency up to lawsuits.

Asked by Nature to respond to concerns about such a precedent, Sherley referred to the appeals court's decision to give him standing. "It should go without saying that I think the deci-
"Adult and embryonic stem cells should not constitute competing areas of research." sion, and the reasoning therein, is correct," he wrote in an e-mail.

From a research perspective, stem cells, whether derived from embryonic or adult tissue, are simply a tool for studying biological systems and developing treatments for diseases - much like knockout mice or biochemical assays in a test tube. No single tool is inherently better than another, but each must be chosen for its use in addressing a specific research question.

For that reason, there is not and should not be a pot of money set aside for research on either embryonic or adult stem cells. Peer review should be enough to decide which projects merit funding. Adult and embryonic stem cells should not constitute competing areas of research - scientists who use these cells in their work should view their studies as complementary.

With Sherley and Deisher's appeal accepted, the original case will now go to court. The government agencies must decide on their next move: they could ask the Court of Appeals to reconsider its decision, or they could appeal to the Supreme Court. Alternatively, they could argue the case and hope to win. All federally funded researchers should watch the case closely; if the government loses, the implications will reach far beyond the stem-cell field.

a database of existing articles. CrossCheck's 83 members have already made available the full text of more than 25 million articles.

What is disheartening is that plagiarism seems pervasive enough to make such precautions necessary. In one notable pilot of the system on three journals, their publisher had to reject $6 \%, 10 \%$ and $23 \%$ of accepted papers, respectively.

Granted, there are reasons to believe that such levels of plagiarism are exceptional. Previous studies of samples on the physics arXiv preprint server (see Nature 444, 524-525; 2006) and of PubMed abstracts (see Nature doi:10.1038/news.2008.520; 2008) found much lower rates. But the reality is that data are sorely lacking on the true extent of plagiarism, whether its prevalence is growing substantially and what differences might exist between disciplines. The hope is that the roll-out of CrossCheck will eventually yield reliable data on such questions over wide swathes of 